\title{
Contact of Socio Economic Position of the Family and Their Member Achievements in Education
}

\author{
K. Gnanamoorthy, \\ Ph.D., Research Scholar, Department of Economics, Presidency College (Autonomous), Chennai, Under the \\ Supervisor and Guidance of Dr.G.Yoganandham.
}

\begin{abstract}
This study examines two important aspects. Firstly, it studies the relationship between SocioEconomic position of the family and achievements of their family members. Secondly, it examined the impact of Socio-Economic position on the academic achievements of the children. For this study eight colleges and two Higher Secondary Schools were selected from Thiruvannamalai District, Tamil Nadu state, India. A sample of 20 students was selected from each college and school. Rank correlation and Chi Square test have been used to test the hypothesis. The findings show positive and strong correlation between Socio-Economic positions and academic achievements of the children.
\end{abstract}

Keywords: Socio-Economic Status, Academic Achievements.

\section{Introduction}

There are several current areas that are most commonly linked to academic performance including school factors, family factors and examine factors. But ones family background has also been found to be most influencing factor. Modern research has found that socio-economic status, parental involvement and family size are particularly important family factors. Family socio-economic status plays an important role in the student's life and outside of school also. socio-economic status has the most important influence on student learning and it includes socio- economic status, two parents versus single parent households, break up, parenting practices and targets, maternal characteristics, family size, and neighborhood.

During the earlier years of child research, the socio-economic status of parents was largely overlooked. It was not until the work of sociologists in the late 1930s that behavioral scientists had firm evidence that welldefined behavioral trends were associated with various levels of socio-economic status. The determination of socio-economic status is closely related with income or earnings and educational level that these two variables are usually used by researchers as valid indices of socio-economic status.

\section{Literature Review}

Many studies by sociologists, economists, statisticians and academicians are conducted to study the correlation between the Socio-Economic status and the academic achievements of students at different levels of their study, in different areas and at different times. Studies have shown repeatedly that Socio-Economic status affects student achievements.

Attinasi (1989) emphasized the importance of making connections early on with examine and family members.

Astin (1993) found that students' socioeconomic status was the best predictor of earning a bachelor's degree after controlling for academic ability.

In addition to the quality of instruction, family Socio-Economic status also influences the quality of the relationship between school performances and parents (Watkins 1997).

Wenglinsky (1998) compared low Socio-Economic status schools with higher Socio-Economic status schools and found several important differences in terms of instructional arrangements, materials, teacher experience, and teacher-student ratios.

Fowler (1999) found that higher neighborhood Socio-Economic status, as measured by the value of owner-occupied housing or by residents' educational attainment, is significantly related to greater school expenditures per student.

Jeynes (2002) showed that there is a positive correlation between Socio-Economic status of a family and the academic achievements of a student.

Hochschild (2003) says that students who have a low Socio-Economic status earn lower test scores and are more likely to drop out of school.

Eamon (2005) believed that low Socio-Economic status negatively affects academic achievements because low Socio-Economic status prevents access to vital resources and creates additional stress at home. 


\section{Methodology}

The problem of the study is to investigate the impact of the Socio-Economic status of the parents on the academic achievements of their children. For the academic achievements of the students we have taken the sample of the students who have passed their Higher Secondary School Examination $\left(12^{\text {th }}\right.$ level examination). For this percentage of marks (Marks obtained/ Total marks * 100) is used to study the academic achievements by the students. It is denoted by Ry. Ry is the ranks of the achievements of children in their Higher Secondary School examination. The population of the study is the male students of Thiruvannamalai district of Tamil Nadu state who have passed their $12^{\text {th }}$ level examination in 2010 and are admitted in any college of the Thiruvannamalai district. A questionnaire was developed and it was administered personally. A sample of five Colleges of the district such as Government Arts College Thiruvannamalai, Aringnar Anna Government Arts College Cheyyar, Chogalingam College Arni, Divya Arts \& Science College Chetpet, and SRK Arts \& Science College Vandavasi. Along with these colleges, Renugambal Arts \& Science College Polur, Annamalai College Thiruvannamalai, Government Poly Technical College Chengam and two Higher Secondary Schools are also taken as a sample of the study. A sample of 200 male students was selected such as 20 students from each college were randomly selected. Socio-Economic status of the parents is taken from the total income of the parents and is ranked in ascending order of their income denoted by Rx. While academic achievements of the students are taken from the $12^{\text {th }}$ class result.

It is not necessary not possible that everyone in the universe will be equally holy in terms of income, money, social status or prestige. Although these are desired by all but everyone not gets them equally distributed in the population. That is why people in the society are ranked according to their income. Hence for this purpose a Spearman's Rank Correlation is used to study the relationship. This is given as under

Where

$$
r_{s}=1-6 \Sigma \mathrm{Di}^{2} / \mathrm{N}\left(\mathrm{N}^{2}-1\right)
$$

$r$ is coefficient of Rank Correlation

$\mathrm{Di}$ is square of the difference between Rx and Ry

$\mathrm{Rx}$ is the ranks of father's income in ascending order

Ry is the ranks of the academic achievements of student on the basis of percentage in their Higher Secondary School examination.

$\mathrm{N}$ is the number of observations such as 200 .

Same can be achieved by using the Chi Square $\chi^{2}$ approach.

\section{Objectives Of The Study}

The study aimed at finding the following objectives

- To see the relationship between the Socio-Economic status of the parents and the admission in the colleges.

- To see the impact of Socio-Economic status on the achievements of the students.

- To find the problems and suggest improvements in the light of findings of the study to the policy makers and planners.

\section{Hypothesis Of The Study}

Firstly, there is a positive relationship between the Socio-Economic status of the parents and the academic achievements of their children.

Secondly, the Socio-Economic status positively effects the academic achievements of their students.

\section{Data Analysis}

To show the number of students admitted in various colleges according to their family income three different income group are made. Here by family income we mean income from any person that is father, mother or both. It is given in the following table No.1.

Table No. 1. Income wise position of students admitted in various colleges

\begin{tabular}{|l|c|c|}
\hline \multicolumn{1}{|c|}{ Income Group } & Number of Students & Percentage \\
\hline $0-25000$ & 18 & 9.0 \\
\hline $25001-50000$ & 98 & 49.0 \\
\hline 50001 and above & 84 & 42.0 \\
\hline Total & 200 & 100 \\
\hline
\end{tabular}

Source: Questionnaire 
The analysis of the table shows that as the income of the family increases the number of students admitted to various colleges also increases. This shows that there is a positive relationship between income of the family and students admission in various colleges.

The important objective of the study is to investigate the impact of Socio-Economic status on the academic achievements of their children. For this, Spearman's Rank Correlation coefficient $\mathbf{r}$ is used.

$$
\text { Here } \mathbf{r}_{\mathbf{s}}=\mathbf{0 . 7 7 6 .}
$$

It shows that there is a strong or high correlation between Socio-Economic status of the family and academic achievements of the students.

Applying the Chi Square $\chi$ test the relationship can also be verified.

The Chi-square distribution contains only one parameter, called the number of degree of freedom (d.f). The formula for Chi-square distribution is as under:-

$\chi^{2}=$ with $(\mathrm{r}-1)(\mathrm{c}-1)$ d.f. $\quad \sum(\mathrm{fo}-\mathrm{fe})^{2} / \mathrm{fe}$

Where fo $=$ observed (Given) frequency.

$\mathrm{fe}=$ expected (Calculated) frequency.

Expected frequency in any cell can be calculated are:-

$\mathrm{fe}=$ Expected frequency $=($ Row total $)($ Column total $)$

Grand Total

It is explained with the help of the following table No. 2.

Table No. 2. Relationship between Socio-Economic status of parents and Academic achievements of the

\begin{tabular}{|lcccc|}
\hline \multicolumn{1}{|c}{ Achievements } & Low & Middle & High & Total \\
High Achievements & 5 & 28 & 61 & 94 \\
Middle Achievements & 12 & 21 & 34 & 67 \\
Low Achievements & 20 & 12 & 07 & 39 \\
Total & 37 & 61 & 102 & 200 \\
\hline
\end{tabular}

Source: Questionnaire

Children

To measure the relationship between Socio-Economic Status and academic achievement of the students Chi-square distribution is used. Calculated Chi-square value was found to be 11.14 as against the table value of 9.49 at $\alpha=0.05$ with $\mathrm{d}$. $\mathrm{f}=4 . \quad\left(\boldsymbol{2}^{2}=11.14>9.49\right)$. So there is significant relationship at 0.05 levels. Hence "There is significant relationship between Socio-Economic Status and academic achievement of students".

\section{Conclusions}

Following conclusion on the basis of objectives and hypothesis can be drawn from the study. There is a positive relationship between the Socio-Economic status of the parents (calculated in terms of family income, either by father, mother or both) and the academic achievements of their children. The analysis of the data shows that the Socio-Economic status of a family positively effects the academic achievements of their children. It is also verified by the strong positive correlation between the two.

\section{Reference:}

[1]. Astin, A. W. (1993), What Matters in College. Liberal Education, 79(4): 4-15

[2]. Attinasi, L. C., Jr. (1989), Getting in: Mexican Americans' Perceptions of University Attendance and the Implications for Freshman Year Persistence. Journal of Higher Education, 60(3):247-277.

[3]. Eamon M K (2005), Social- Demographic, School, Neighborhood and Parenting Influences on Academic Achievements of Latino Young Adolecsents. Journal of Youth and Adolescence. 34(2):163-175.

[4]. Flowers, L. A., and Pascarella, E. T. (1999). Does College Racial Composition Influence the Openness to Diversity of AfricanAmerican Students? Journal of College Student Development, 40(4): 405-417.

[5]. Hoschchild J L (2003), Social Class in Public Schools. Journal of Social Issues, 59(4):821-840

[6]. Jeynes W H (2002), Examining the Effects of Parental Absence on The Academic Achievements of Adolescents: The Challenge of Controlling for Family Income. Journal of family and Economic Issues. 23(2):132-141.

[7]. Pillai and Bagavathi (2001), Statistics theory and Practice, S.Chand and Company Ltd, pp.790-805.

[8]. Watkins, T. J. (1997), Teacher Communications, Child Achievement, and Parent Traits in Parent Involvement Models. Journal of Educational Research, 91(1): 3-14.

[9]. Wenglinsky, H. (1998), Finance Equalization and Within-School Equity: The Relationship Between Education Spending and the Social Distribution of Achievement. Educational Evaluation and Policy Analysis, 20(4): 269-283. 